発語失行症における発話時の構音器官の動態 一ファイバースコープおよびX線マイクロビームシステムによる観測——

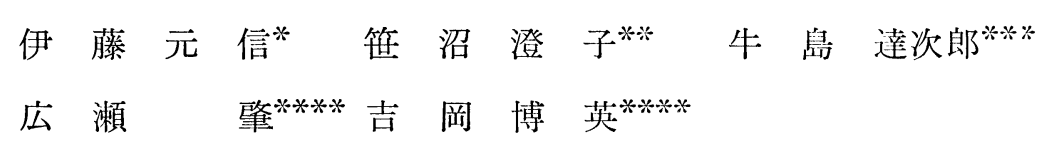

\title{
Articulatory Dynamics in a Patient with Apraxia of Speech
}

-Fiberscopic and X-Ray Microbeam Observations-

\author{
Motonobu Itoh, Sumiko Sasanuma, Tatsujiro Ushijima, \\ Hajime Hirose and Hirohide Yoshioka
}

\begin{abstract}
To obtain an accurate picture of the syndrome called apraxia of speech and to gain some insight into its underlying mechanisms, observations of the articulatory movements were made of a patient diagnosed as having apraxia of speech by means of a fiberoptic system and an $\mathrm{X}$-ray microbeam system. The data obtained from the apraxic subject were compared with those of the normal and dysarthric subjects.

The results indicated that the articulatory movements of the apraxic patient were clearly different from those of the normal as well as the dysarthric subjects in terms of the patterns, consistency and velocity of movements. Based on these observations, possible mechanisms responsible for the syndrome called apraxia of speech were discussed.
\end{abstract}

\section{I . はじめに}

脳損傷に伴って発現する言浯障害としては，言語表象 の操作機能の障害である失語症 (aphasia) と, 神経・筋 系の病变に基づく構音障害である麻痺性構音障害 (dysarthria）とが良く知られている.

ところで, 大脳皮質の前言語野(ブローカ領域)に損傷

* 東京都老人総合研究所

** 横浜国立大学・東京都老人総合研究所

*** 東京大学医学部耳帠咽喉科教空

**** 東京大学医学部音声言語医学研究施設
を受け (多くの場合, 部位は推定されたものであるが), その言語症状から失語症と診断された患者のなかに，一 貫性のない構音の誤り, ぎごちない構音動作, 発話速度 ・リズム・抑揚など韻律面での異常といった諸症状を特 徵的に示す患者がいることが，古くから多くの臨床家に よって報告されてきた。

最近に至り, Darley (1968)1)は, このような諸症状を 一括して, 構音動作に際しての発語運動の企画 (motor programming) の障害を反映するものであるとし，発語 失行症 (apraxia of speech) と呼ぶことを提唱した. 脳 損傷に伴って生じる言語障害に関するこのような新しい 
視点の提供は，その後の研究を促進し，以後，発語失行 症に関する多数の報告がなされてきた（Johns と Darley, $1970^{2)}$; Aten $ら, 1971^{33}$, Deal と Darley, $1972^{4)}$; Rosenbek 5, $1973 \mathbf{a}^{5)}, 1973 b^{6)}$; Skelly 5 ; 1974) ; Trost と Canter, 1974 ${ }^{8}$; Keith と Aronson, $1975^{9)}$; LaPointe と Johns, $1975^{10)}$; Dabul と Bollier, $1976^{11)}$ ); この上うな研究の大多数は, 発語失行症患者 の発話の特徵を音部論的に分析した子のであり，これら の報作を通じて，発語失行症の症状が次第に浮き活りに されつつある。

発話の䧣害としての発語失行症の実態を明らかにする ためには，発話の音刣分析を系統的に行らことが重要で あることはいうまでもない、しかし，発語運動の企画の 障害が楧音器官の運動にどら反哒されているかを知るた めには, 発話時の構音器官の運動解析が不可欠である. しかしながら，この方面の検索にはほとんど手がつけら れて㧍らずわずかに Schankweiler ら (1968) ${ }^{122}$ の筋 電図的手法を用いた研究絬果が堀少されているにすぎな (法1).

今回われわれは Darley ら $5^{1,2,30)}$ の記述に步てはまる 諸症状を示す 1 症例に関して発話時の構音器官の運動解

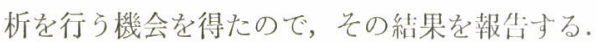

\section{II. 症例}

今回钼察の対象としたのは，61歳男子1名である（な 㧍，钼察結果の記述に岕たっては，正常人または他種の 模音障害を伴う症例について，同一の方法で観測された 絬果と刘比させた).

木症例の現病歴拉よび言語検查結果は以下のと扮りで ある. 1970年 3 月14日,ゴルフ中に突然右腕の感覚がな くなりめまいが約30秒続いた．休息後，それらの症状 が消光たので一人で車を運転して州ろうとし，車をスタ 一トさせた直後に再びめまいが生じ，前方の車に追突し た、幸い，双方に怪我がなかったので，近くの交番に行 き警察官に事故を報告しよらとしたところ，一語も発す ることができず，直ちに付近の病院に入院した。 1 週間 目にやっと声が出るようになったが，言語音らしきもの が出せるようになるには約 1 カ月かかった。 入院時に は，臨床検查上特記すべき異常は認められなかったが， 上記の症状から, 脳血栓と診断された。発症後 7 カ月の

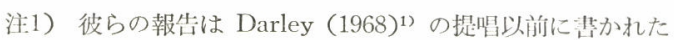
ものであり, 発語失行症といら用語は用いられていな い.しかし, 彼らの症例に扔ける “phonetic disintegration”あるいは “residual articulatory disorder” と いった表現であらわされている症状は，明らかにDarley のいら発語失行症の症状と一致する。

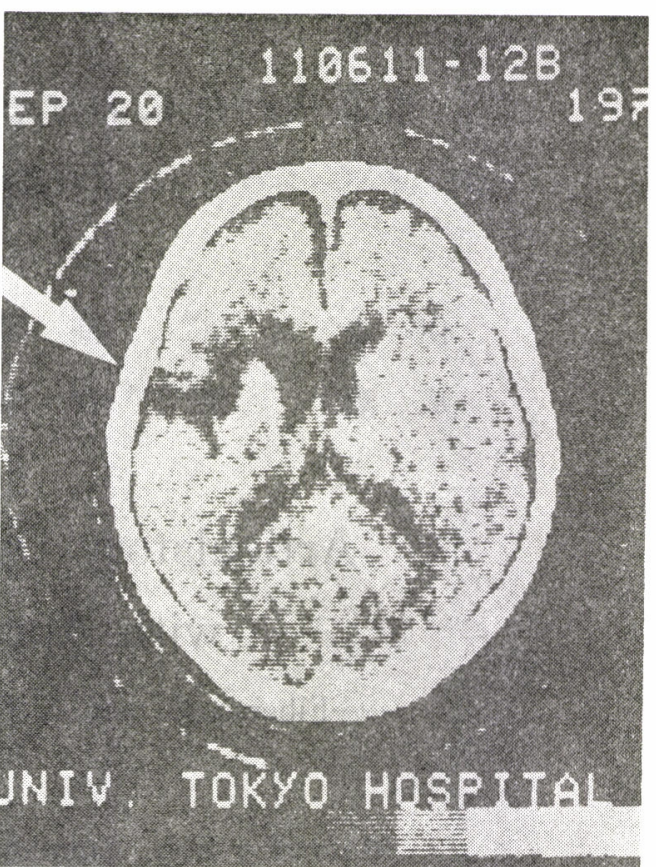

図 1 ，本症例の CT スキャン図（矢印は损伤部 位をあらわす)

時点で，はじめてのくわしい言語検査を受け，その結 果, 書字子読字能力の軽微な低下を除いて言語能力その ものは良く保たれていることが明らかとなったが，一貫 性のない構音の詋りやプロソディーの変化が顕著である ことが垫められ，Darley ら ${ }^{1,2)}$ の記述による発語失行症 と讋断された (Sasanuma, 1971) ${ }^{13)}$.な扝，発症 6 年後 の1976年8月に施行された CT (computerized axial tomography）により，左半球シルビウス渆前部付近の 皮質から皮質下にかけて病変が確認された（网1）.

\section{III. ファイバースコープによる発話時の口蓋 帆の運動観察}

\section{1. 目的}

発語失行症に和ける構音の䛊りの発生機序に閔与る手 がかりを得る目的で，構音器官としては艺の動作が比較 的単純な口盍帆の運動を観察した。

\section{2. 方法}

観測は Sawashima と Ushijima $(1971)^{14)}$ 打よび沢 島ら $(1976)^{15)}$ の方法により行った。すなわち，鼻腔 内に挿入したファイバースュープを通じて口蓋帆を每秒 50 コマで撮影し，口蓝帆上面の輪郭の高さを計测し，そ の上下運動の時間経過をプロットした。なお，音声を同 時録音し，音声とフィルムとを同期させた。各音素に対 


\section{/teNteNteNteN /}
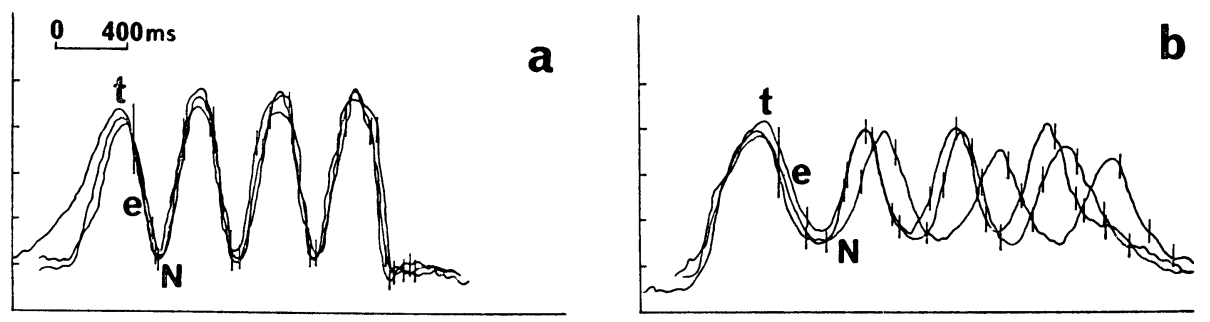

\section{/deeneedesu/}
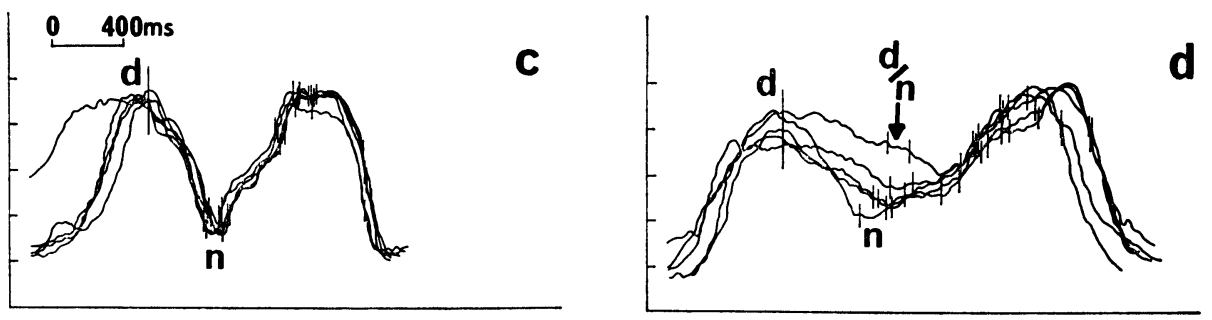

\section{/teedeNdesu/}

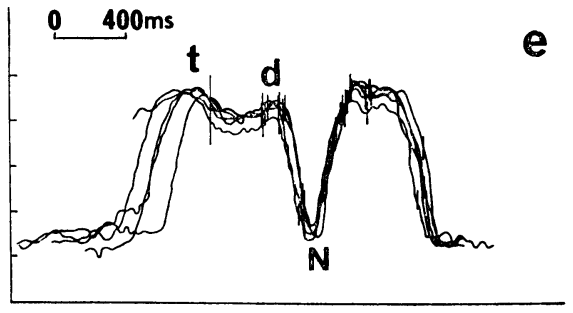

NORMAL

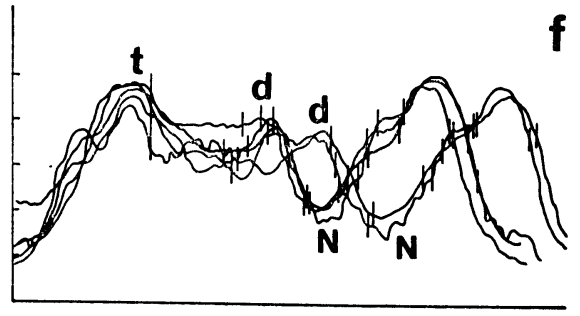

APRAXIC

図 2 然意味音節およよ゙有意味語発話時の口莣帆の迎動パタンの再現性 （左：正常考，右：発語失行症患者）なお，乙の図はシネフィ ルム 1 コマごとに测定した口蓋帆の高さを時閒軸上に点としてプ ロットした後，それらの点を線で結んだあのである．每秒50コマ

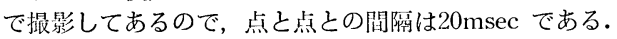

応する時間区分はオシログラフ・トレースにより決定し た。

検査語としては，無意味音節のくりかえしおよび有意味 語を用いた。無意味音節のくりかえしは/teNteNteNteN/ で，これを 3 回くりかえさせた，有意味語は，非鼻子音

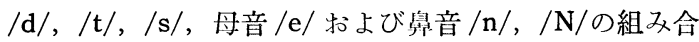

わせによる 4 モーラの，アクセント核のない「泥㵋」 「静寧」「青年」「停年」「停電」「声援」「点影」「精 鋭」の 8 語である.これらの語を「一です」というフ レームを付して発話させた. 発話順序はランダムにし， 各語につき 5 回ずつ発話させた. 実際にはこれらの検査 語を書いた字カードを提示して，検者がまず音読し，そ 
れを模做させる形で患者に発話させた，発話速度につい ては，検者が示寸普通の会話速度に近づけるよう指示し たが，患者の発話速度は正常者のそれに比較して明らか に遅かった。

\section{3. 結 果}

1）運動パタンの一般的特徽

正常者の口莣帆の運動パタンに比較して，この発語失 行症患者は以下に述べるよらな多くの特異なパタンを示 した。

(1)運動の再現性

因 2 は種々の発話条件下での，正常者（左）拉よび発 語失行症患者（右）の口蓋帆の高さの時間的变化を示 す。槛軸は洔間, 縱軸は計測上の任意に定めた尺度, 曲 線上の短い綎線は各音素に対応する時問区分，長い綎線 は基準時点としての第一音節の母音の立ち上がりを，そ れぞれ示している. 上段は無意味音節のくりかえし/teNteNteNteN/の 3 回の運動パタンを重ねて描いたもの であり，他は有意味語の 5 回の運動パタンを重ねて描い たものである. 正常者の/teNteNteNteN/(上段)では， 口蓋帆は音節ごとに振幅の大きな上下動を規則正しくく りかえして拉り，かつ，3回の発話間で，運動パタンの 一致度が高い，これに対して，発語失行症患者の発話で は，正常者でみられるような規則性をやや久くと同時 に, 3 回の発話䦓での变動が著しい，有意味語に関して も同様で，正常者では，同一発話条件下で高い再現性が みられるが，発語失行痕患者では著しい変動が生じてい る. 口蓝帆の高さの著しい变動（上下の変動）飞加兄 て，封間的な変動（左右の変動）も認められる。たと兄 ば/deeneedesu/（中段）に打いて，語頭の/d/から/n/ にかけて，発話ごとに口薄帆の下降の勾配が著しく変化 しているだけでなく／d/から/n/までの経過時間にも変

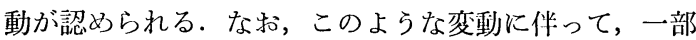
の発話では同時に記録した音声信号に打いて/n/から /d/ への音䫓変化が生じている．しかし，このような变 動を示しながらも，語頭の/d/から/n/にかけて下降し た後上昇するという “基本的”な運動パタンは 5 回のく りかえしを通じて常に維持されている．次の/teedeNdesu/（下段）では変動が大きく， 口蓋帆の運動パタンは 一見ランダムに見えるが，ここでも“基本的”な運動ハ タンは維持されている.すなわち, 語頭の/t/の後に若 干下降するがその高さが一定区間維持された後に，/d/ の直後で大きく下降し，その後に上昇するといらパタン が5回の発話のすべてに其通して認められる。ただし， 語頭の/t/から/d/にかけての所要時間が発話ごとに著し く変動しているのが特徵的である。

(2) 鼠音・非帠子音の口薀帆の高さ

発語失行症患者の運動パタンの第 2 の特徵として，叟 音・非舁子音ともに口盙帆が中間的な位置をとることが しばしば観察された。たとえば，図 3 に示すよらに/ eneedesu/の正常者の発話（左）では，非舀子音/s/, $/ \mathrm{d} /$ 亿対する口蓋帆の位置は高く，鼻音/n/亿対する口蓋 帆の位置は低い, $/ \mathrm{n} /$ の発話に際し, 口蓅帆の位置は安 静呼吸時の位㯰までは下降しないが，すべての母音およ び非帠子音にくらべ低い，これに対して，発語失行症患 者の発話（右）では，語中の/d/ に対する口蓝帆の位置 が低くなっている反面，/n/ 亿対与る位置が高く，雨者 の高さが接近している．な拉，音声サンプルに扔いて， この $/ \mathrm{n} /$ は $/ \mathrm{d} /$ へと音䯪変化している. / $/$ 亿ついても同 様なことが観察される，正常者の場合 (図 2 の左)，/N/ のための口莣帆の高さは家静呼吸時の位置に到達ないし 接近しているのに対し, 発語失行症患者の発話（図 2 の右）では，安静呼吸時の位置よりもかなり高い位置に 西ることが多い。

2）予測による構音結合の状態

璉続構音の際に，粼接あるいは近接する音が瓦いに影 響しあう現象は榵音結合 (coarticulation) として知ら れて抢り (Daniloff と Hammarberg, 1973) $)^{16)}$, 運動 制御機構の構音への関与を直接反映するものとして, 多
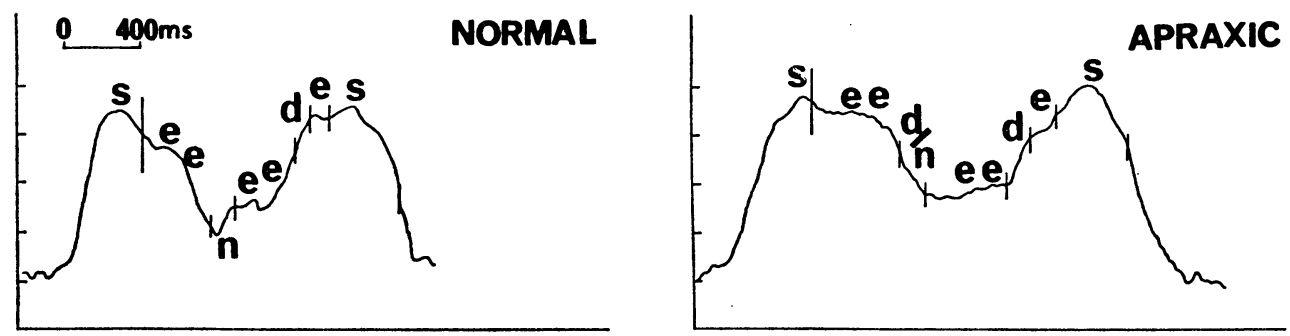

図 3 /seeneedesu/ 発話時の口蓋帆の運動パタン (左 : 正常者, 右 : 発語失行症患者) 

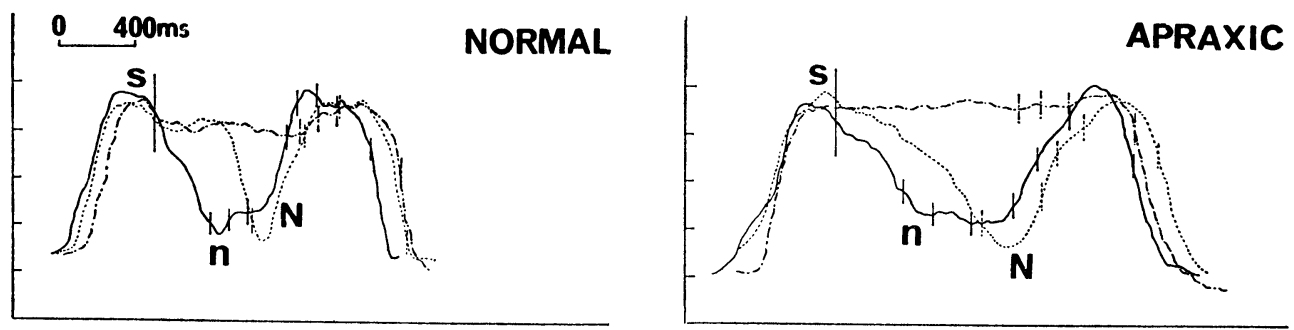

図 43 種類の音環境下での口蓋帆の運動パタン （左：正常者, 右 : 発語失行症患者）

/ pa pa pa. , , /
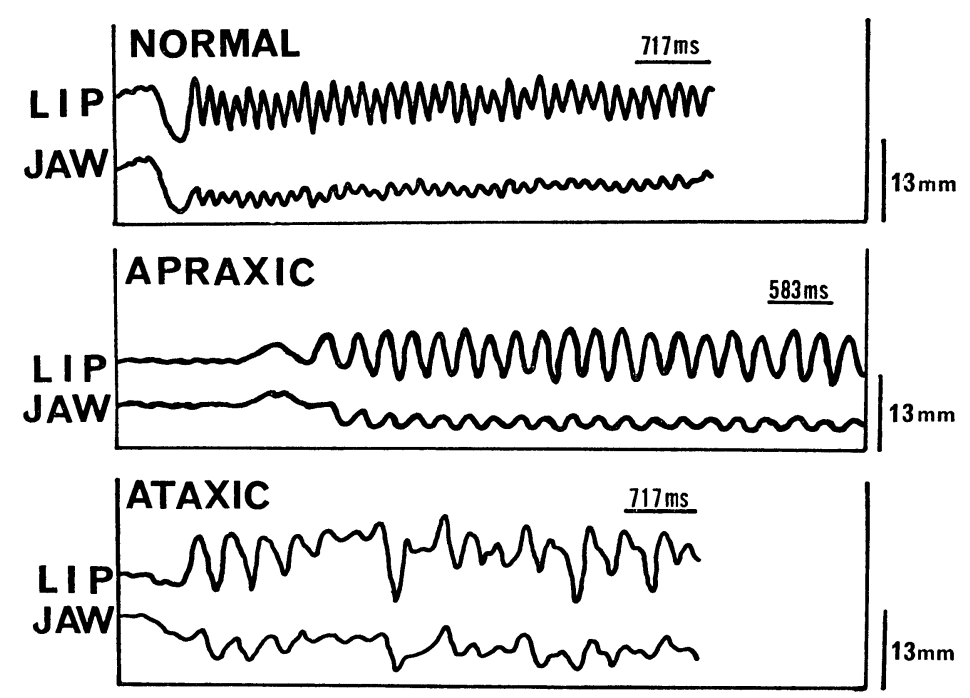

図 5 単音節 / pa/ くりかえし時の下口唇および下顎の運動パタン （上から正常者, 発語失行症患者, 小脳変性症患者）なお, 発語失行症患者の図の時聞軸は, 他の 2 者のそれに比しいく ぶん拡大されている.

くの研究者の注目を集めている。このような構音結合と いう観点から正常者と発語失行症患者の口蓋帆の運動ハ タンを比較してみた。

図4は,/see'eedesu/,/seeneNdesu/および/see'eNdesu/ の運動パタンの比較である. 正常者の発話（左）に扔い て，一点鎖線で示してある非鼻子音環境の/see'eedesu/ では，口蓋帆は一貫して高い位置に保たれているのに対 して，実線で示してある鼻音環境/seeneNdesu/では/n/ に対する口蓋帆の下降が/s/の直後から始まっており， いわゆる予測に上る構音結合 (anticipatory coarticulation）が認められる. 同じような現象は，発語失行症患
者の発話（右）においても同様に観察される.また，こ のような予測による構音結合は, 鼻音を含む他の発話 /deeneedesu/, /seeneedesu/および/teeneNdesu/にお いても, 正常者, 発語失行症患者ともに認められた. し かし, 図4 の左右の図をさらに吟味すると, 正常者の発 話（左）では，点線で示してある/see'eNdesu/ と执い て, 撥音/N/に対する口蓋帆の下降が/s/の直後からは 始まらず，途中までは，一点鎖線で示してある非鼻子音 環境の/see'eedesu/ と同じ高い位置に保たれている.こ れに対して, 発語失行症患者の発話（右）では, / see'eNdesu/，/seeneNdesu/ともに，口蓋帆は語頭の/s/の 
直後から下降を開始していることが注目される.

\section{X線マイクロビームシステムによる発話} 時の構音器官の運動観測

\section{1. 目的}

発語失行症患者の発話時の構音器官の動態をさらにく わしく調べるために，複数の構音器官の同時観測を行う とともに，各構音器官の運動速度の測定を行った。

\section{2. 方 法}

X線マイクロビームシステム (Kiritani ら， 1975) $)^{17)}$ を用い，口蓋帆，奥舌，下口唇，下頱の発話中の動きを 観察した（ただし，観察の対象とした構音器官は検查語 によって異なる，な扔，患者の義歯のため，舌尖および 中舌の運動の観察は不可能であった). 検查語としては, 音節/pa/, / ta/, / $/ \mathrm{ka} /, / \mathrm{teN} /, / \mathrm{pataka} /$ などのくりか えしおよび有意味語としての「泥濘」(/deenee/) をcarrier phrase に插入したものを用いた。
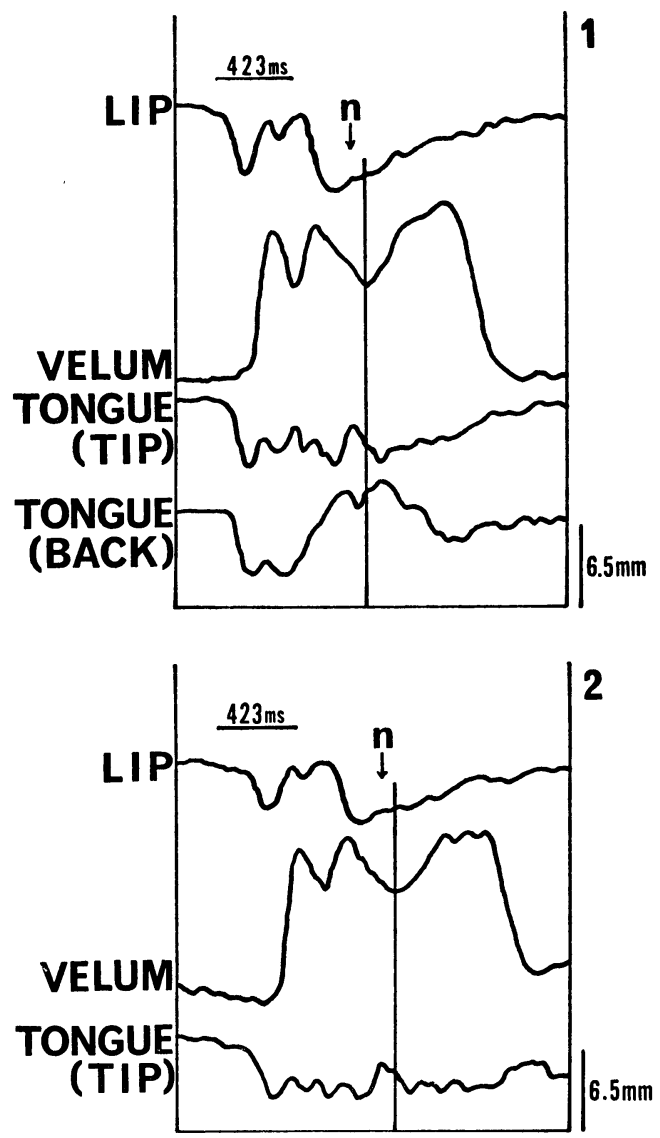

3. 結 果

1）複数の構音器官の間の時間的協調性

(1)音節のくりかえし

図 5 は，/pa/を速やかにくりかえして発話した際の， 下口唇および下顎の上下方向の運動パタンを示す（な お，ここでの正常者拉よび小脳変性症患者のデータは, 広瀨ら $(1977)^{18)}$ 叔よび Hirose ら (1978) ${ }^{19)}$ から引用 した).この図から明らかなよらに，発語失行症患者の 発話 (中段) 飞打いても，正常者の発話 (上段) と同様 に下口唇と下顎の運動の同期性は良く保たれている。 た，小脳变性定患者の発話 (下段) にみられるような運 動の範囲や速度の大きなバラッキや，運動方向の変換の 困難さは認められない。なお，他の音節 $(/ \mathrm{ta} /, / \mathrm{ka} /$, /teN/）の速やかなくりか兄しに扔いても，同様の結果 が得られている.

(2)/deenee/発話時

次に, 図 6 は正常者が carrier phrase 中の/deenee/
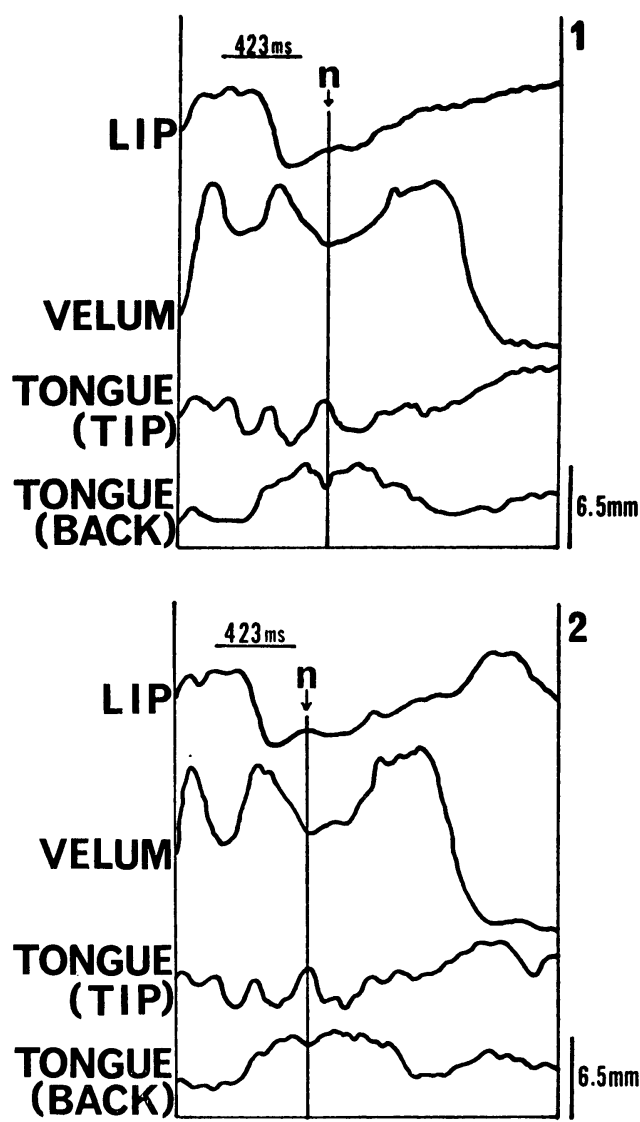

図 6 Carrier phrase 中の/deenee/ 発話時の運動パタン（正常者の普通の速度 （左）と遲い速度 (右) では 2 问の発話の比較) 
を普通の速度（左：4Hzのクリック音をイヤホーンでき き，これに発話リズムを合わせるようにしたもの）と遅 い速度（右：3Hz のクリック音を基準としたもの）で2 回ずつ発話した際の運動パタン（下口唇・口蓋帆・舌尖

・奥舌の上下運動パタン．ただし，普通の速度での 2 回 日の発話に関しては奥舌のデータはない)の比較であ る.

ここで特に注目すべき点は，/n/ に対する口蓋帆の下 降運動之舌尖の上昇運動との時間関係である. 滔通の速 度の発話（左）と遅い速度の発話（右）とでは, 雨者の 間に若干の差があるが (/n/ のために口蓋帆が下降し終 わり，上昇を開始する時点を基準にした場合一図中縦 線で示してある—，遅い速度の発話では普通の速度の 発話にくらべ，舌尖の上昇ピークがやや遅れる傾向にあ る)，それぞれ 2 回の発話を通じて，口薪帆の下降運動 と舌尖の上昇運動の時間関係にほとんど变動がないこと
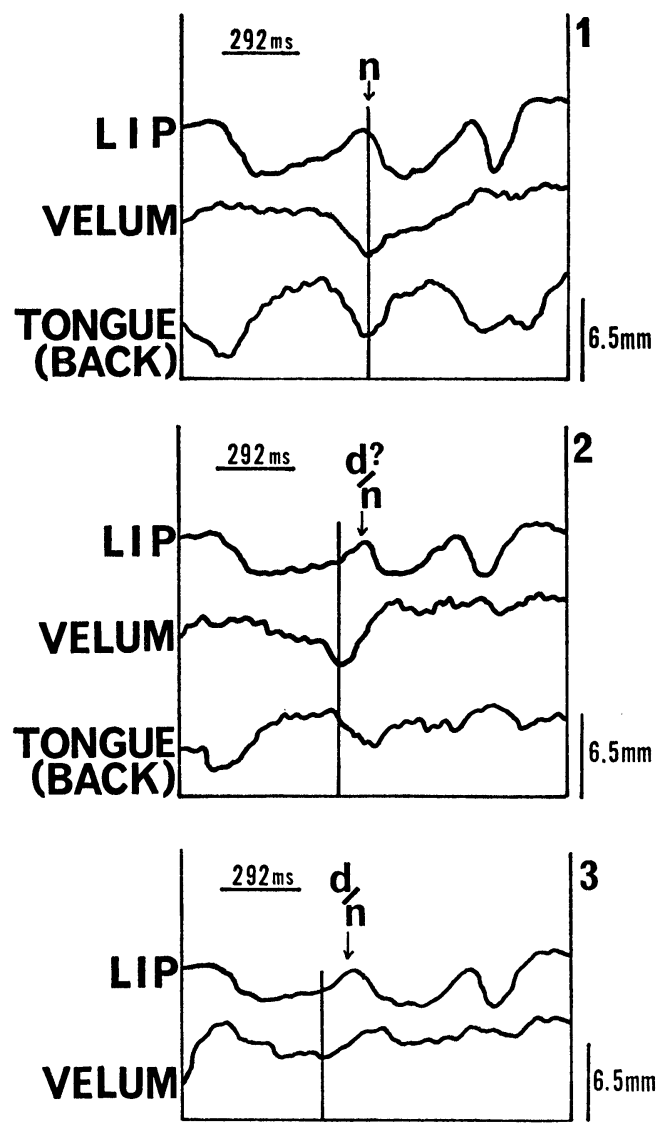

図 7 Carrier phrase 中の/deenee/ 発話時の運動パタ ン（発語失行症患者の 3 回の発話）なお，データ 処理の都合上，図6の時間軸に比し，乙の図のそれ はやや拡大されている. そのため, タイミングのズ レがいくぶん誇張されている.
が明らかである。

一方, 図 7 は, 発語失行症患者が carrier phrase 中 の/deenee/を 3 回発話した際の運動パタン（下口唇・ロ 蓋帆・奥舌の上下運動パタン.ただし， 3 回目は前 2 者 の運動パタンのみ）の比較である.すでに述べたように， 義歯のため舌尖の運動パタンは得られていないが, /n/ のための歯茎部閉鎖時に，下口唇と奥舌に特徵的な運動 パタンが珰められているので，それらの運動と口蓋帆の 運動とのタイミングを発話ごとに比較することを武み た.

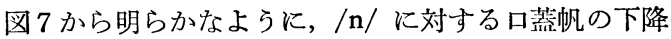
運動と他の構音器官の運動との時間関係が発話ごとに著 しく変動することが認められる。すなわち，1では/n/ に対する口蓋帆の下降の谷が，下口唇の上昇のピーク （抢そらく舌尖の上昇のピーク）と奥舌の下降の谷とに ほぼ同期しているが，2では $/ \mathrm{n} /$ に対する口蓋帆の下降 の谷が下口唇の上昇のピークと奥舌の下降の谷に先行し ている. 3 亿打いても/n/ 亿対する口蓋帆の谷が下口唇

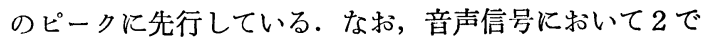
は/n/音の非鼻音化傾向が認められ， 3 では/n/から $/ \mathrm{d} /$ への明らかな音の置换が生じている。

2）運動の速度

図 8 は, 正常者（速い発話と遅い発話）, 発語失行症 患者, 小脳変性症患者, 筋萎縮性側索硬化症 (ALS) 患 者の/pa/のくりかえし時の下口唇の運動速度を比較した ものである(ここでの正常者, 小脳変性症患者および ALS 患者のデータは Hirose ら (1978) $)^{19)}$ から引用し た)、な拉，ここでは下口唇の変位から下顎の変位分を 差し引いて運動速度を算出してある.

この図から明らかなように，正常者の速い発話では， 下口唇の開閉速度が速く，しか子開放時，閉鎖時とも速 度はほぼ均一である。これに対して, 発語失行症患者の 発話では，運動速度は正常者のそれの $1 / 2$ 程度であり， ALS の運動速度に近い。な拈，正常者の遅い発話の場 合には閉鎖区間が延びているが变位そのものは速い発話 時とほぼ同じであり，発語失行症の発話の遇さとは様相 を異にしている．しかし，発語失行症患者の発話におい ては，小脳変性症患者抢よび ALS 患者の発話にみられ るような運動速度のバラッキ（ALS 患者では速度のバ ラッキは小脳変性症患者ほど顕著ではないが，な秥，あ る程度認められる) はほとんどないなおお，各種の音節 を速やかにくりかえした場合のその他の構音器官の運動 速度に関しても，表 1 にみられるごとく，発語失行症患 者の運動速度は正常者のそれにくらべて著しく遅い（こ こでの正常者のデータは，沢島，広瀬 $(1977)^{20)}$ から引 

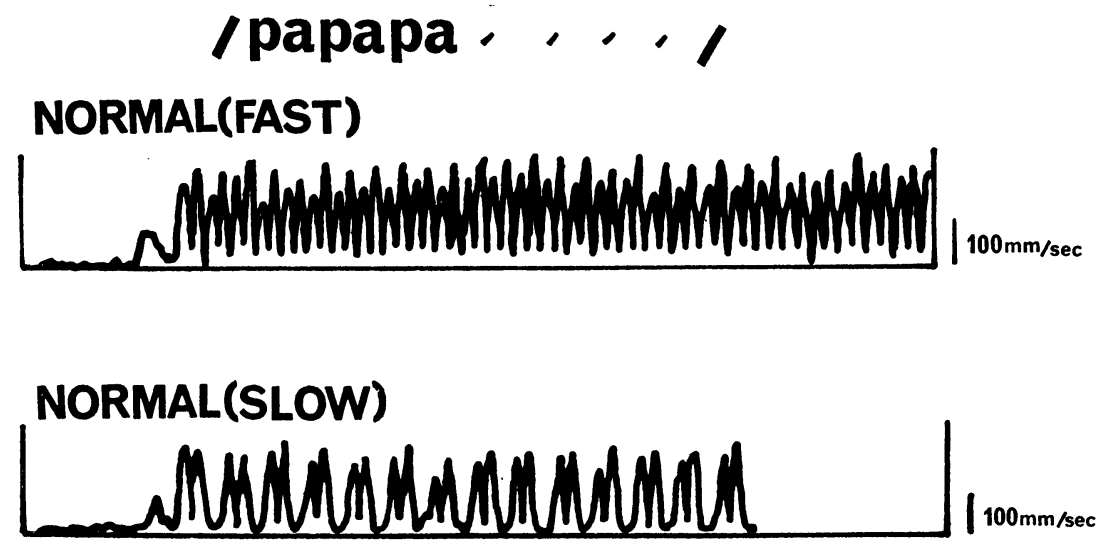

APRAXIC

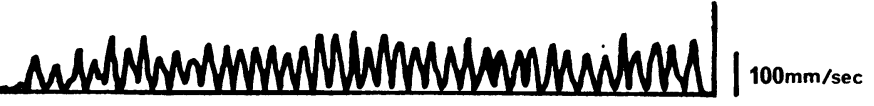
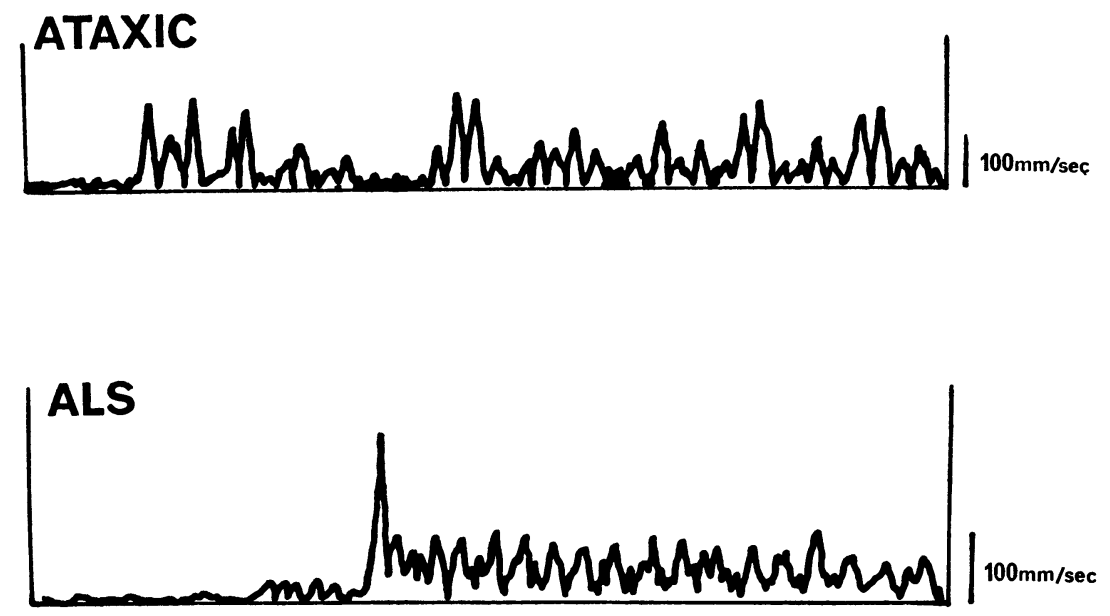

図 8 単音節 /pa/ くりかえし時の下口唇の運動速度 (上から正常者の速い発話, 正常者の遅い発話, 発語失行症患者・小脳変性症患者·ALS 患者の発話)

用した).

\section{V. 考察}

ファイバースコープによる観察で得られた結果のらち 最も重要と思われるものは, 発語失行症患者の口蓋帆の 運動パタンが, 同一発話条件下の発話ごとに著しい変動 を示しながらも，特定の音連鎖における “基本的”な運 動パタンは正常者のそれに近似しているという事実であ る.たとえば，/deeneedesu/（図 2-d）に打いて，語頭 の/d/から/n/にかけて発話ごとに口蓋帆の下降の勾 配 が著しく変化し，/d/から/n/までの経過時間にも変動 が認められている.このような変動に伴って一部の発話 では/n/から/d/への明らかな音の置換が生じているが, 予測による構音結合としての口蓋帆の下降というパタン は常に保たれているといえよう．この事実は，本症例に みられた運動パタンの変動ならびに 音韻変化が, target 
表 1 発話時の構音器官の運動速度:

\begin{tabular}{|c|c|c|c|}
\hline \multirow[b]{2}{*}{ 構音器官 } & \multirow[b]{2}{*}{ 構音の種 類 } & \multicolumn{2}{|c|}{ 運動速度 $(\mathrm{mm} / \mathrm{sec})$} \\
\hline & & 正常者 & 発語失行症患者 \\
\hline 下ロ唇 & /pa/ のくりかえし & $190 \sim 250$ & $81 \sim 136$ \\
\hline \multirow{2}{*}{ 舌 体 } & /ka/ のくりかえし & & $56 \sim 118$ \\
\hline & $\begin{array}{l}\text { /pataka/のくりかえ } \\
\text { し時の / ka/の構音時 }\end{array}$ & $200 \sim 220$ & $87 \sim 149$ \\
\hline 口蓋帆 & /teN/のくりかえし & 最大 105 & $28 \sim 93$ \\
\hline
\end{tabular}

音素の選択ないし指定の誤り，すなわち，音韻操作の誤 り，飞基づくものとは考えがたいことを示陖している. なぜなら，もし観察された $/ \mathrm{n} /$ か $/ \mathrm{d} /$ への音韻変化が， 音素の選択の誤りに基づくものであるとすれば，“基本 的”な運動パタンそのものが異なるはずであろう。すな わち，非鼻子音環境/deedeedesu/となり，口蓋帆は一貫 して高い位置に保たれているはずである.とすれば，こ こで観察された発語失行症患者の発話時の口蓝帆の運動 パタンの特異性はどのような要因によるものであろう か.

異なった音環境下で，口蓋帆の高さに関する一定の値 を実現するためには，口蓋帆の高さの变位や，上昇・下 降の速度を考虑に入れた運動指令の編成（あるいは企 画）が，発話に先行してなされる必要があると考えら れる. 事実, Ushijima と Hirose $(1974)^{21}$, 沢自ら $(1976)^{15)}$ ，牛島ら $(1976)^{22)}$ 扎よびUshijima ら $(1977)^{23)}$ の正常者を対象としたファイバースコープと筋電図によ る口蓋帆の動態解析の結果は, 音環境や発話速度に応じ て，運動指令の編成がたくみになされていることを示し ている. 今回の観察結果は, 発語失行症患者の発話時に は，このような運動指令の編成が円消に行われていない ことを示すものであると考えられる.

加えて, 本症例に扔いては, 複数の構音器官の時間的 協調性の乱れが存在することを示唆する結果が得られて いる.すなわち，すでに，述べたように／deeneedesu/ を 5 回くりかえした際に, 語頭の/d/から/n/の間の母音 区間の持続時間が発話ごとに著しく変動し，しかも一部 の発話に $/ \mathrm{n} /$ から $/ \mathrm{d} /$ への明らかな音韻変化が認められ る.つまり, /n/ のための口蓋帆の下降と歯茎部閉鎖の ための舌尖の上昇運動との間に発話ごとにタイミングの ズレが生じていることが推測される.

な怙，音韻変化が生じた発話は，そのようなタイミン グのズレが著しい場合と考兄られよう. 複数の構音器官 の運動の同時記録を行ったX線マイクロビームシステム による観察結果は上記のような解釈を支持するものであ
る.すなわち, carrier phrase 中の/deenee/を数回発話 した場合, /n/ に対与る口蓋帆の下降運動と他の構音器 官の運動との時間的関係が発話ごとに変動していること が観察された注2)。しかし，ここで興味深いことは，音 節のくりかえしという比較的単純な構音では, 複数の構 音器官の間の時間的協調性が良く保たれていることであ る.この事実は, 複数の構音器官の間の時間的協調性の 乱れが，より複雑な音連銷に括いての及顕在化すること を示唆している.このような所見は, 発語失行症の症状 の臨床観察とも良く一致している。

発語運動の中双制御機構の解明には汪ど遠い現状であ るが, 発話に際しては, 個々の構音器官の制御に加え て, さらに複数の構音器官の統合的制御が行われている との考鼻も提出されている (Kent ら，1974) ${ }^{24)}$. このよ うな考皇に従えば, 発語失行症に和いては, 個々の構音 器官の運動制御の障害の他に, 複数の構音器官の統合的 制御にも問題があると考学ることができよう.

ところで, 発語失行症患者の発話/seeneNdesu/, /deeneedesu/, /seeneedesu/拈よび/teeneNdesu/ におい て，予測による構音結合としての口蓋帆の下降現象が認 められた. このことは, 発話のための運動の企画の障害 とされる発語失行症に扮いても, 構音動作の実行に際し て, 後に続く segment の構音の指定を先行する segment に持ちこむという基本的な操作は保たれているこ とを示唆している.ただし，この基本的操作は必ずしも 常に正確に実現されているとは限らない. 因4 亿みられ るように, /see'eNdesu/に抢いては, 口盟帆の下降開始 のタイミングのズレがある.つまり，運動の企画面の障 害がここにも反咉されているといえよう注3).

注2）ファイバースコープによる観察時, X線マイクロビー ムシステムによる観察時ともに口蓋帆と舌の運動との間 にタイミングのズレが認められたが，乙れら 2 種類の観 察時の間で, ズレの方向が逆になっている. すなわち, ファイバースコープによる観察時では, 崡茎部閉鎖のた めの舌尖の上昇運動に対して, 口蓋帆の下降運動に遅れ が生じているのが示唆されたのに対し，X線マイクロビ 一ムシステムによる観察時には, 口蓋帆の運動に対し て，下口唇の上昇（すなわち，おそらく舌尖の上后）運 動に屝れがみられた.なぜてのような差異が生じたかは 明らかではないが，両観察時の発話速度の違いが関係し ているかもしれない.

注3）なお， $\mathrm{CVV}^{\prime} \mathrm{VN}$ という音素連続において，予測によ る構音結合の䇭囲に “制限” が加わるという現象は，ア メリカ英語で実証された Moll と Daniloff (1971) の口蓋帆の構音結合のモデルでは，説明できない事実と して, すでに, Ushijima と Hirose (1974) ${ }^{21)}$ および 沢島ら (1976) ${ }^{15)}$ によって指摘されているが，ての現象 が，なぜ生じるかについてはいまだ明らかではない。し かし，予测による構皆結合は，後続する segment を同 定しやすくするための知党的な手がかりを与えるとする 
な抢，「発語失行症」という用語は，Darley $(1968)^{1)}$ の提唱以後，特に米国に执いて広く用いられてきている が，最近に至り，この用語をめぐっての論争が展開され ている.すなわち, Martin $\left(1974^{25)}, 1975^{26)}\right)$ は，「発 語失行症」の示す構音の誤りは, 発語運動の企画の障害 とはいえず，音䫓操作の誤りに基づくものであり，従っ て, 「発語失行症」といら用語は適切でないと主张して いる.

Martin は，失語症患者（発語失行症患者を含む）に おける構音の誤りを弁別素性を用いて分析した諸研究 (Lecours と Lhemitte, 1969 ${ }^{27)}$; Martin と Rigrodsky, $1974^{28)}$; Trost と Canter, $1974^{8)}$ ) に言及し, これらの 研究で対象とした患者の構音の誤りの大多数が弁別素性

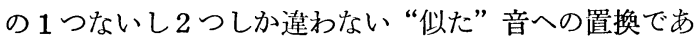
ることを指摘している，彼によれば，このように関連性 の高い音への置き換えは，「発語失行症」の特徵として 指摘されてきたランダムな構音の誤りにも明確な規則性 が存在することを意味して扣り，そのような誴りは音暗 操作の誤り,すなわち, 音韻論的（言語学的）領域の問 題である.

このようなMartinの主張に対して, Aten ら(1975) ${ }^{29)}$ は，音素産生のためのプログラミングの障害は音䫓操作 の障害 (音䫓論的障害) とは独立して生じうるという主 張を固持している.すなわち，Martin が証拠として取 り上げた諸研究においても, 発語失行症患者が必ずしも 常に“似た” 音への置換を示してはいないこと，また，

“似た”音への置換の存在が必ずしも発語運動の企画领 域の問題を否定するものではないことを指摘し反論して いる.

われわれの観察絬果は Aten らの主㤝の一部を支持す るものと考光られる.すなわち,/deeneedesu/を数回く りかえして発話した際に，一部の発話では $/ \mathrm{n} /$ から / d/ への音韻変化が認められたが，ここでの誤りは弁別素性 が 2 つしか異ならない音（鼻音一非鼻音，継続音一非継 続音）への置換である.しかし，ここでの音韻変化は音 素の選択の詔り,つまり, 音韻操作の誤り, としては説 明困難であることはすでに述べた．

ところで，表 2 は発症後 7 カ月括よび今回の検討時 (発症後 6 年 4 力月) 以行った音韻分析の結果であ る注4). 表 2 から明らかなように，発症後 7 カ月の時点 での主要な誤りは，音位転換（metathesis）および逆行

Moll と Daniloff (1971) ${ }^{31)}$ の指摘が正しいとすれば, ての日本語に特有の現象も, 積極的な運動指令に基づく あのであると考えるのが妥当であろう. 発語失行症患者 の発話ではこのような現象に破綻が生じているのは興味 深い.
表 2 発語失行症患者の読み詋りについての音韻分析の結果

\begin{tabular}{|c|c|c|}
\hline 譟りの種類* & 発症後 7 カ月 & 発症後 6 年 4 力月 \\
\hline \multirow{3}{*}{\multicolumn{3}{|c|}{$\begin{array}{l}\text { I . 葄 換 } \\
\text { 1. 音位転換 } \\
\text { (1) 単語内 }\end{array}$}} \\
\hline & & \\
\hline & & \\
\hline a. 隣接 & 18 & 1 \\
\hline b. 非隣接 & 2 & 0 \\
\hline (2) 単語間 & 3 & 0 \\
\hline 2. 逆行性同化 & & \\
\hline (1) 単語内 & 14 & 0 \\
\hline (2) 単語間 & 7 & 0 \\
\hline 3. 順向性同化 & 4 & 1 \\
\hline 4. ランダムな置換 & 13 & 2 \\
\hline II. 付 加 & 4 & 0 \\
\hline III. 省 & 2 & 0 \\
\hline IV. 反 復 & 1 & 0 \\
\hline 計 & 68 & 4 \\
\hline
\end{tabular}

* 音の歪みと自己修正については集計していない.

性の音の同化 (backward assimilation) である.この うち特に音位転換抢よび語の境界を越えてあらわれてい る逆行性の音の同化は target 音素の選択ないし指定の 誤りを反咉するものと解釈された。 このような観察結果 飞基づき Sasanuma $(1971)^{13)}$ は，発症 7 カ月の時点で の本症例の発話面の障害は純粋に発語運動に限定された ものではなく，音韻論的（言語学的）領域にもまたがる 問題であるうと推諭した. しかしながら，表 2 の右闌が 示すように，発症後 6 年 4 力月経過した今回の音韻分析 の絬果では, 满音の誤り総数が著しく減少しているのみ でなく，音位転換や語の境界を越えて生じる逆行性の音 の同化は汪とんど認められなくなって拈り，このことか ら，初期にみられた音䫓論的障害はほとしど消失してい るといえよう。しかし一方，一貫性のない構音の㒭り， 權音動作のぎこちなさ, 類吃症状, あるいは, 発話速度 ・強勢・抑掦などの韶律面の異常は依然として著明であ り, 従って, 本症例の現時点に抢ける障害は発話運動面 に比較的限定されたものとみることができよう．

いいか觉ると， Darley ら ${ }^{1,2,300}$ の記述による発語失 行症の臨未症状のなかには, 発語運動の破綻に由来する もの之同時に，音䫓論的領域にもまたがるものが含まれ ている場合がありらる（本症例の発症７カ月目の検查時 の所見がこれに相当する）と考学られるが，今回われわ れが用いた音竞分析招よび発語運動解析の方法を組み合 わせることによって，これら 2 つの要因をある程度分離

注4）音韻分析は Sasanuma (1971) ${ }^{13)}$ の方法に従った. す なわち, 298 語からなる文章を音読させ, 音読の誤り を，表 2 に示すにうなカテゴリーに分類した.なお，力 テゴリー別の就りの例を付表に示してある. 
付表 発語失行症患者の訪み勏りの例

\begin{tabular}{|c|c|}
\hline 誤りの種類 & 例 \% \\
\hline
\end{tabular}

I. 置換

1. 音位転換

(1). 単語内

a. 隣接

b. 非隣接

koto $\longrightarrow$ toko

(2). 単語間

2. 逆行性同化

(1). 単語内

(2). 単語間

3 . 順向性同化

4.ランダムな䠑換

II . 付加

III. 省畛

IV . 反復

※矢印の左側は targetとしての䍩語ないし句，右側は反危 をそそれぞれ示す。

することが可能になると思われる，な拉，われわれは発 語失行症の本質は発語運動面に限定された障害であると の立場をとる. 従って，7カ月の時点での本症例の障害 像は, Sasanuma (1971) ${ }^{13)}$ が指摘したように，発語失 行症に音韻論的障害が合作したものと考皇るのが妥当で あろう。

な拉，発語失行症が発語運動の障害としての dysarthria'とは発生機序のみならず症状自体その性質を異に していることはすでに多くの報告が指摘している（たと えば, Johns と Darley, 19702); Darley ら, 1975 ${ }^{30)}$ ). 今回の観察結果も, 発語失行症の構音器官の動態が, 少 なくとも典型的な小脳変性症や筋萎縮性側索硬化症に基 づく構音障害のそれとは異質なるのであることを示唆し ている。

\section{VI. おわりに}

発語失行症の本態を明らか炕す研究の一環として, Darley らの記述に相当する発語失行症状を呈する 1 症 例の発話時の構音器官の運動解析を, ファイバースコー プ抢よびX線マイクロビームシステムを用いて行った.

その結果, 発語失行症患者の発話時の秱音運動は正常 者のそれとは明らかに異なること，さらに，小脳変性症 例や筋萎縮性側索硬化症例とも様相を異にしていること が確かめられた。

発語失行症の本態を明らかにすることは，その競断法 打よび治療法を確立するために重要であるばかりでな く，発話過程に括ける高次中枢の果たす役割に関して贵 重な情報を与えうるものと思われる。そのためには，今
後症例を重䄈るとともに，特定の症例を長期にわたって 継続的に観察すること, 発話時の運動解析と音韻分析を 平行して行うなど多角的なアプローチをとることが必要 であろう。

本研究に対し，多くので助言，ご協力をいただいた東京大学 医学部音声言語医学研究施設沢島政行教授に樑く感謝する. な押，本研究は文部省科学研究费 (No.140003, No.148271, No. 157515，No. 248363，No. 310707）の援助を受けたととを 付記し，謝意を表する。

本研究の一部は，第21回および第22回日本音声言語医学会総 会において発表した。

\section{文献}

1) Darley, F. L. : Apraxia of Speech : 107 years of Terminological Confusion. Paper presented at the 44th American Speech and Hearing Association Convention, 1968.

2) Johns, D.F., \& Darley, F. L. : Phonemic Variability in Apraxia of Speech. Journal of Speech and Hearing Research, $13: 556-583,1970$.

3) Aten, J. L., Johns, D. F. \& Darley, F. L. : Auditory Perception of Sequenced Words in Apraxia of Speech. Journal of Speech and Hearing Research, $14: 131-143,1971$.

4) Deal, J. L. \& Darley, F. L.: The Influence of Linguistic and Situational Variables on Phonemic Accuracy in Apraxia of Speech. Journal of Speech and Hearing Research, $15: 639-653.1972$.

5) Rosenbek, I., Lemme, M.L., Ahearn, M. B., Harris, E. H., \& Wertz, R.T.; A Treatment for Apraxia of Speech in Adults. Journal of Speech and Hearing Disorders, $38 ; 462-472.1973 a$.

6) Rosenbek, J., Wertz, R. T. \& Darley, F. L. : Oral Sensation and Perception in Apraxia of Speech and" Aphasia. Journal of Speech and Hearing Research, $16: 22-36$, 1973b.

7) Skelly, M., Schinsky, L., Smith, R. W., \& Fust, R.S. : American Indian Sign (AMERIND) as a Facilitator of Verbalization for the Oral Verbal Apraxic. Journal of Speech and Hearing Disorders, $39:$ 445-456, 1974.

8) Trost, J. E., \& Canter, G. J. : Apraxia of Speech in Patients with Broca's Aphasia: A Study of Phoneme Production Accuracy and Error Patterns. Brain and Language, $1: 63-69,1974$.

9) Keith, R. L. \& Aronson, A.E. : Singing as Ther- 
apy for Apraxia of Speech and Aphasia : Report of a Case. Brain and Language, $2: 483-488,1975$.

10) LaPointe, L. L., \& Johns, D. F. : Some Phonemic Characteristics in Apraxia of Speech. Journal of Communication Disorders, $8: 259-269,1975$.

11) Dabul, B. \& Bollier, B. : Therapeutic Approaches to Apraxia. Journal of Speech and Hearing Dis orders, 41 : 268-276, 1976.

12) Shankweiler, D., Harris, K.S., \& Taylor, M. L. : Electromyographic Studies of Articulation in Aphasia. Archives of Physical Medicine and $\mathrm{Re}-$ habilitation, $49: 1-8,1968$.

13) Sasanuma, S. : Speech Characteristics of a $\mathrm{Pa}-$ tient with Apraxia of 'Speech. Annual Bulletin, Research Institute of Logopedics and Phoniatrics, University of Tokyo, $5: 85-89.1971$.

14) Sawashima, M., \& Ushijima, T. : Use of the Fiberscope in Speech Research. Annual Bulletin, Research Institute of Logopedics and Phoniatrics, University of Tokyo, $5: 25-34,1971$.

15）沢島政行, 牛島達次郎, 公瀬 匴：調音時の口蓋帆 の運動. 日本音響学会音声研究委員会資料, S75-56, 1976.

16) Daniloff, R. G., \& Hammarberg, R. E. : On Defining Coarticulation. Journal of Phonetics, $1: 239$ $-248,1973$.

17) Kiritani, S., Ito, K., \& Fujimura, O. : TonguePellet Tracking by a Computer-Controlled X-ray Microbeam System. Journal of Acoustical Society of America, 57 ; 1516-1520, 1975.

18）広瀬 肇, 桐谷 滋, 吉岡博英, 沢帠政行, 牛島達

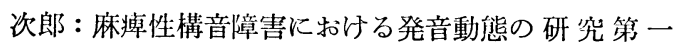
報; 小脳変性症について. 日耳鼻, $80: 25-32$, 1977.

19) Hirose, H., Kiritani, S., Ushijima, T., \& Sawashima, M. : Analysis of Abnormal Articulatory Dynamics in two [Dysarthric Patients. Journal of Speech and Hearing Disorders, $43 ; 96-105$, 1978.

20）沢島政行，公瀬 整：調音運動のタイミングについ て. 昭和 52 年度科学研究費「特定言語」沢島班資料 No. 2, 1977.
21) Ushijima, T., \& Hirose, H. : Electromyographic Study of the Velum During Speech. Journal of Phonetics, 2 : 315-326, 1974.

22）牛息達次䬦, 㳄岛政行, 広瀬肇：口蓋帆の調音運 動の解析一ーアクセントの有無と発話速度の影響 一, 日本音響学会音声研究委員会資料, S 76-31, 1976.

23) Ushijima, T., Hirose, H., \& Sawashima, M. : Effects of Accent and Speaking Rate on the Control of Velar Articulation. Annual Bulletin, Research Institute of Logopedics and Phoniatrics, University of Tokyo, $11: 23-30,1977$.

24) Kent, R. D., Carney, P. J., \& Severeid, L. R. : Velar Movement and Timing : Evaluation of a Model for Binary Control. Journal of Speech and Hearing Research, $17: 470-488,1974$.

25) Martin, A. D. : Some Objections to the Term Apra xia of Speech. Journal of Speech and Hearing, Disorders, 39 : 53-64, 1974.

26) Martin, A. D. : Reply to Aten, Darley, Deal, and Johns. Journal of Speech and Hearing Disorders, $40: 420-422,1975$.

27) Lecours, A. R., \& Lhermitte, F. : Phonemic Paraphasias: Linguistic Structures and Tentative Hypotheses. Cortex, $5:$ 193-228, 1969.

28) Martin, A. D., \& Rigrodsky, S. : An Investigation of Phonological Impairment in Aphasia. Part 2 : Distinctive Feature Analysis of Phonemic Commutation Errors in Aphasia. Cortex, 10:329346, 1974.

29) Aten, J. L., Darley, F. L., Deal, J. L., \& Johns, D. F. : Comment on A. D. Martin's "Some Objections to the Term Apraxia of Speech." Journal of Speech and Hearing Disorders, 40:416-420, 1975.

30) Darley, F. L., Aronson, A.E., \& Brown, J. R. : Motor Speech Disorders. W. B. Saunders, 1975.

31) Moll, K. L., \& Daniloff, R. G. : Investigation of the Timing of the Velar Movements During Speech. Journal of Acoustical Society of Amerca, $50: 678-684,1971$. 